\title{
The role of Nucularia perrinii Batt. (Chenopodiaceae) in the camel-based Sahrawi social-ecological system
}

\author{
Gabriele Volpato ${ }^{1}$ and Antonello Di Nardo $^{2^{*}}$ (D)
}

\begin{abstract}
Background: Pastoral social-ecological systems (SESs) are adaptive and complex systems rooted in the extensive exploitation of forage plants for livestock-based livelihoods and culture. There are species and relations that are foundational to the existence of these SESs. Nucularia perrinii Batt. (Chenopodiaceae) is an endemic halophyte plant of central and western Sahara seldom cited in the scientific literature. The objective of this study was to investigate the role of this plant in the SES of the Sahrawi camel nomads of Western Sahara.
\end{abstract}

Methods: The data analyzed were collected in the Sahrawi refugee camps of Algeria and in Western Sahara between 2006 and 2010. Fieldwork included semi-structured $(n=38)$ and retrospective $(n=12)$ interviews with Sahrawi refugees, nomads, and camel owners about N. perrinii and associated topics (e.g. distribution, importance for camels, camel diseases, associated grazing practices, other forage plants, etc.).

Results: Askaf, as the Sahrawi call the plant, is crucial to camels' survival, providing salts and water even during dry spells. It holds a pivotal role in the Sahrawi culture, defining the geographical boundaries of the Sahrawi SES and relating the grazing territory with the taste it gives to camel milk, which support the inclusion of askaf as a main element of Sahrawi cultural identity.

Conclusions: We argue that N. perrinii ties the ecology of the western Sahara desert with camel husbandry and associated livelihoods, and further with the culture and worldview of the Sahrawi nomads. We stress the keystone role that some forage plants may have in extensive pastoral SESs worldwide.

Keywords: Pastoral nomads, Salty pastures, Dromedary camel, Sahara, Grazing resources, Milk taste, Cultural identity

\section{Background}

'Social-ecological systems' (SESs) are defined as complex, integrated systems in which humans and nature coevolve, emphasising, with the use of this term, the artificial and arbitrary delineation between a social and an ecological realm $[1,2]$. The SES approach recognises that there is an intimate interaction between local ecosystems and their dynamics, on the one hand, and the social, cultural, and economic characteristics and dynamics of communities and societies, on the other hand. SESs are based on specific sets of animal and plant species (including humans) and on their interactions [3, 4]. Pastoral SESs, in particular, depend on livestock

\footnotetext{
* Correspondence: antonello.di-nardo@pirbright.ac.uk

${ }^{2}$ The Pirbright Institute, Pirbright, Woking, Surrey, UK

Full list of author information is available at the end of the article
}

species, on forage plants, on the technical relation deployed to feed livestock (e.g. mobility), and on the social and cultural norms and beliefs that glue these relations in a whole [5]. Grazing species, livestock portfolio, and humans are the backbone of complex systems aimed at utilising marginal territories through technical relations based on humans' and livestock mobility $[6,7]$. Among the forage species, one or more of them may have a key role in providing subsistence to distinct livestock species. These plants have deep material and cultural importance among distinct pastoral populations: they define and influence pastoralists' grazing territories and livelihood practices; they are objects of knowledge accumulation and sharing (e.g. naming and terminology, ethnobiological and ethnoecological knowledge); they have important roles 
in narratives or symbolism (e.g. the species is tied to myths and ancestors); and they have a unique position in cultural identity (i.e. in defining human groups and their territories, beliefs, and values).

To explore these themes, we address the material and cultural importance of grazing species in extensive pastoral SESs focusing on the role of Nucularia perrinii Batt. (Chenopodiaceae) in the SES of the Sahrawi camel nomads of Western Sahara. The Sahrawi have relied on camels (as well as on small ruminants), on local desert resources, and on a high degree of mobility for their livelihoods for about fifteen hundred years. They traditionally inhabited coastal areas of northwestern Africa including Western Sahara, Northern Mauritania, and part of Southwestern Algeria, and were socially organised into different tribes (e.g. Reguibat, Oulad Delim, Oulad Tidrarin, etc.) [8-11]. In 1975, following Morocco's occupation of Western Sahara, about 70,000 Sahrawi fled the Moroccan army [12], becoming refugees. Nowadays, after sixteen years of war (1975-1991) between Morocco and the Sahrawi's armed political organization, the Polisario Front, and the exclusion of refugees from most of their former grazing territories, about 165,000 Sahrawi live in four refugee camps located on a desert plateau called Hamada, close to the Algerian town of Tindouf $[13,14]$. In the camps, refugees rely on food aid [12], while seeking to improve their quality of life through an informal economy, engaging in remunerated labor (e.g. as butchers, mechanics, construction workers, etc.) and expanding trading routes through the camps from Mali, Mauritania, Algeria, and Spain [13, 15]. Besides the camps, the Sahrawi have political control over the Eastern part of the Western Sahara, the so-called 'liberated territories'. Pastoral areas within the 'liberated territories' and their biological resources are important to the refugees' struggle to recover traditional livelihoods and cultural and social practices, from camel husbandry to medicinal plant use $[16,17]$, as well as to engage in income generating activities [18]. By accessing and using these lands, refugees reduce their dependence on food aid by recovering a much-desired traditional lifestyle and authentic food products, with their taste, and associated cultural values $[14,15,19]$. Today, camel husbandry is practiced in the 'liberated territories' (within the regions of Zemmur to the north and Tiris to the south; Figs. 1, 2, and 3) as well as, to a lesser extent, in the surroundings of the refugee camps. Across these areas, the climate is arid and continental, [20], and average annual rainfall is of 30$50 \mathrm{~mm}$, with recurrent droughts. The most important pastures are Acacia tortilis Hayne, N. perrinii, Salsola tetrandra Forssk., Panicum turgidum Forssk., and Astragalus and Stipagrostis species [21]. The presence of these pastures, coupled with the adaptation of camels to dry environments, make human utilisation of the desert possible. Among the more than one hundred plant species characterising the grazing resources of

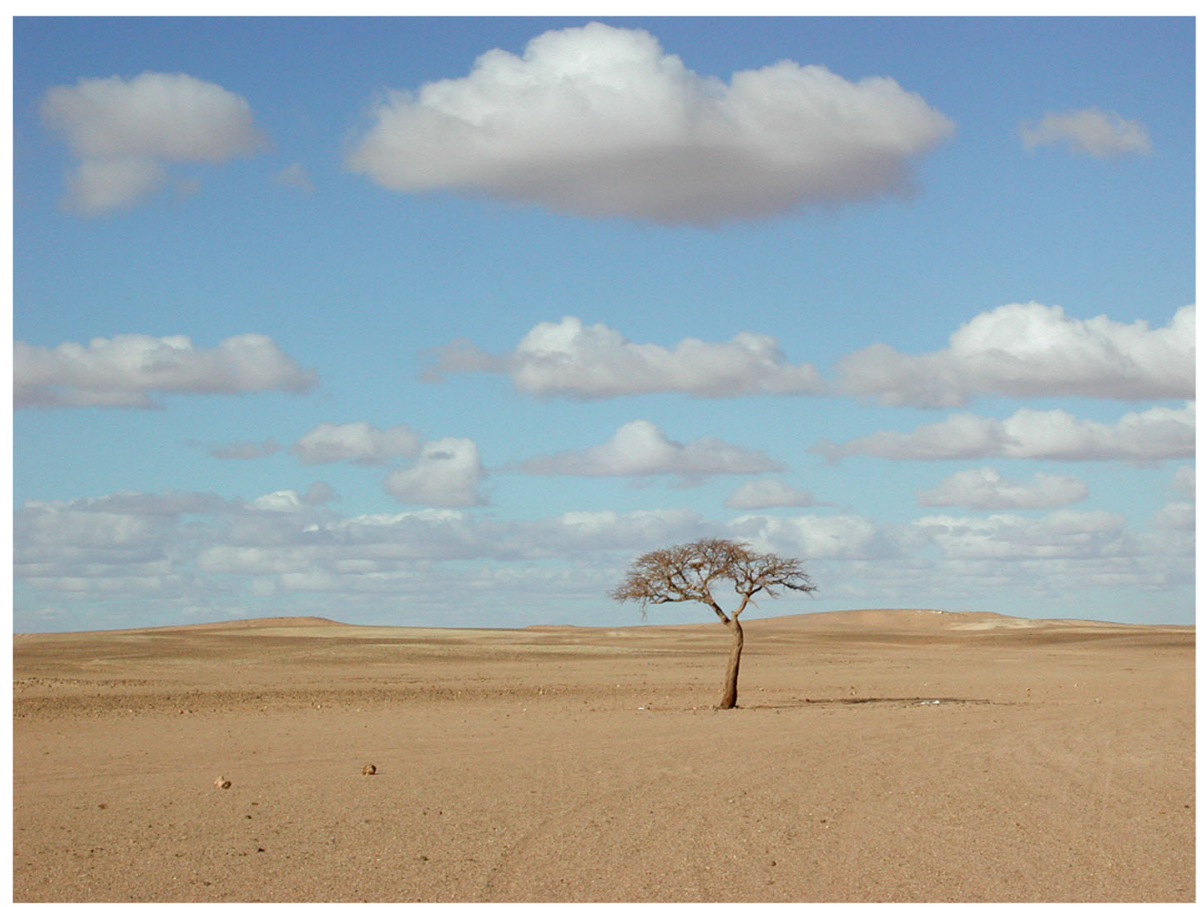

Fig. 1 A solitary Acacia tree in the barren landscape of the Hammada of Tindouf (GV) 


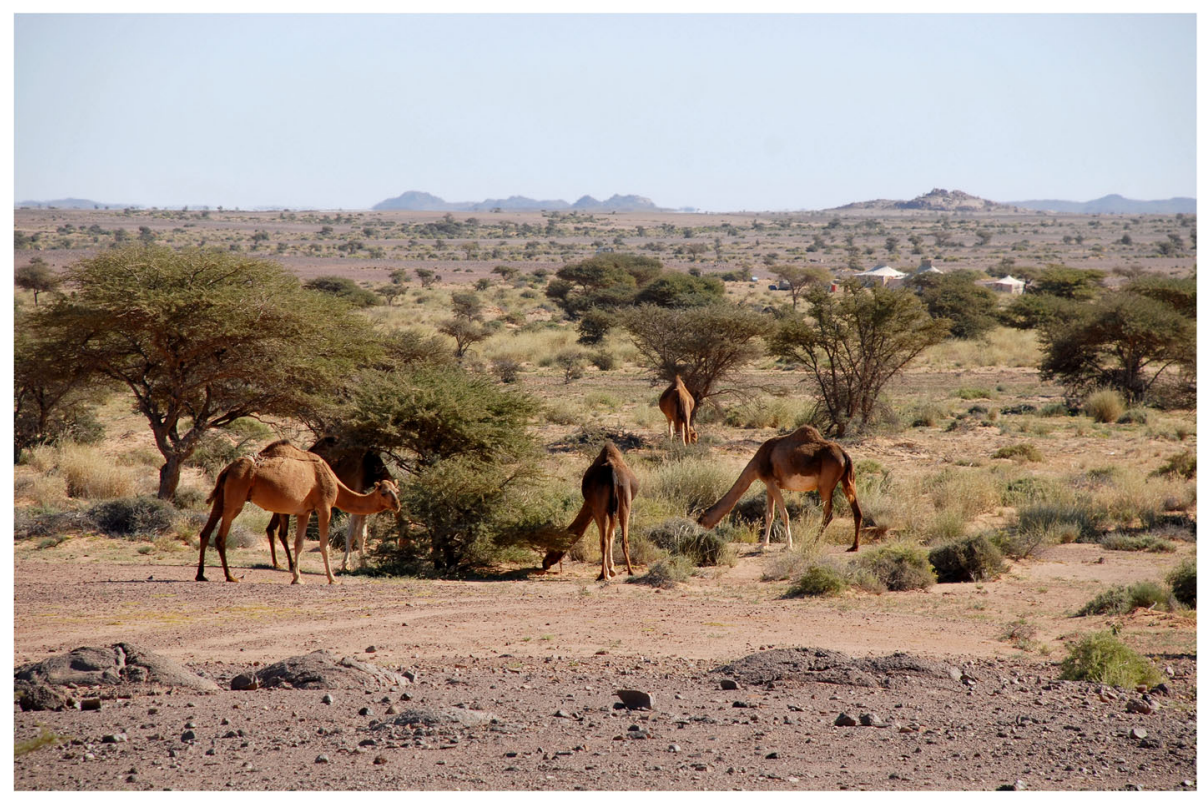

Fig. 2 The Acacia-Panicum vegetation of Zemmur (GV)

western Sahara ${ }^{1}$, a central role and position is given to an endemic halophyte plant, $N$. perrinii or askaf, as it is locally called.

In spite of its importance for pastoralism in western Sahara, there is little information in the literature about this small desert shrub; there are no studies about its ecology or its chemical content, and it is usually cited only in ethnographic accounts about western Saharan nomads and in regional plant lists [10, 22-27].
Typing 'Nucularia perrinii' into Web of Science (http://webofknowledge.com/UA) returns just 1 hit, from our own previous work on Sahrawi pastoralism [28], whereas typing 'Nucularia perrini' (the form in which the scientific name is often misspelled) results in 2 hits, related to research on desert locusts $[29,30]$. In Google Scholar (https://scholar.google.com/), the figures are of 24 and 63 hits, respectively. Besides reports of its endemic condition in western and central Sahara,

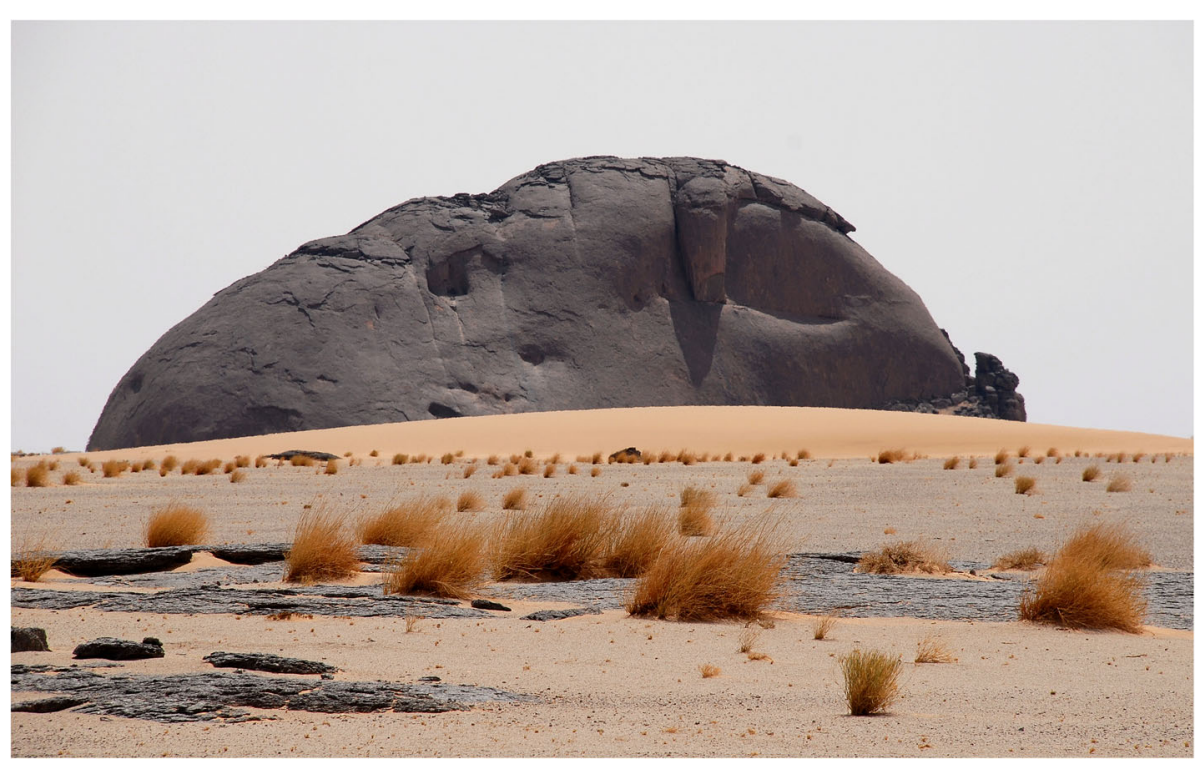

Fig. 3 A black granite hill in Tiris (GV) 
few information are available about its real distribution [31]. Bromatological studies have been recently conducted by Correra [32].

In this paper, we discuss the importance of $N$. perrinii for the Sahrawi camel-based SES and for contemporary Sahrawi refugees in the camps of west Algeria. We first describe the methodology used for this study. Thus, we present and discuss the results focusing first on the botanical (e.g. ecology, distribution), ethnobotanical (e.g. direct uses), and ethnotaxonomic aspects of $N$. perrinii, and then on its key role for camel health and survival in western Sahara and on the strategies adopted by camel nomads to lead their camels to graze from askaf. We further discuss its cultural importance in terms of the taste that it gives to camel milk, in terms of its role in defining the Sahrawi's customary territory and its favourable characteristics for camel husbandry, and, based on all this, on its role to define Sahrawi cultural and political identity.

\section{Methods}

The data analysed in this paper were collected in the Sahrawi refugee camps and in the Polisario-controlled 'liberated territories' of Western Sahara between 2006 and 2010. Ethnobotanical and ethnobiological fieldwork was carried out in accordance with standard texts [33-35], consisting of anthropological fieldwork methods such as participant observation and interviews $[36,37]$. Fieldwork included semi-structured $(n=38)$ and retrospective $(n=12)$ interviews with Sahrawi refugees, nomads, and camel owners about $N$. perrinii and associated topics (e.g. distribution, importance for camels, camel diseases, associated grazing practices, other forage plants, etc.). Interviews were conducted in Hassaniya (the Arabic language with a Berber substrate spoken by the Sahrawi) and Spanish: a local research assistant asked the questions in Hassaniya and translated the answers back into Spanish, which is the second most frequently spoken language among the Sahrawi. To ensure that, during the interview process, no mistakes were made in translation and to clarify doubtful information, interviews were recorded and transcribed with the help of the same research assistant. Qualitative data were coded and analyzed narratively (description, explanation, interpretation, quotations) using NVivo 9 (QSR International Pty Ltd.).

Botanical observations on the vegetation of the liberated territories and on the presence and distribution of $N$. perrinii were conducted and merged with data retrieved from the literature about the species' distribution. Voucher specimens were collected with informants through a 'walk in the woods' approach [34] in the Hamada of Tindouf and across the 'liberated territories', on five independent missions between 2006 and 2009.
Plant nomenclature follows the Sahara and Western Sahara botanical standard treatises [26, 27, 38, 39] and the International Plant Name Index (www.ipni.org). Voucher specimens were deposited in the National Herbarium of The Netherlands (Wageningen Branch Herbarium Vadense). Herbarium specimens for $N$. perrinii are GV1047 and GV2042.

\section{Results and discussion \\ Botanical and phytogeographical aspects}

A brief botanical description of the plant is given by Ozenda [27] in his treatise on Saharan flora: the species is a shrub about $50 \mathrm{~cm}$ tall, characterised by opposed branches and leaves, fleshy and coriaceos leaves (Fig. 4), and small yellow flowers appearing axillary to leaves; stems are white with pinkish extremities, and a characteristic bell-shaped hard shell develops around the fruits (Fig. 5). The plant is endemic to the central and western Sahara desert where it grows in rocky and gravel plains either in flat, hilly, or mountainous areas. Sometimes, in salty depressions, it forms almost monospecific populations. It was first identified in 1900 by Battandier after the collections of Perrin in Touat and Tidikelt (Central Sahara) [40, 41]. It is known to Arabic speaking pastoralists as askaf (or âskâf, āskāf) [42] and to Tamachek speaking Tuareg as tassak [43].

Based on available data in botanical literature, ethnographic accounts, our observations during fieldwork, and of a map drawn by Quezel [44] (pg 514), we present in Fig. 6 a map of the distribution of N. perrinii within a geographical range that includes Libya, Chad, Niger, Mali, Algeria, Mauritania and Western Sahara. According to Lebrun [45], it is a western saharo-sindian species, along with other species such as Crotalaria saharae Coss., Reseda villosa Coss., and Randonia Africana Coss. These species live across western and part of central Sahara, and usually their range stops at east along a line between Bengasi and the Chad-Libya border [45]. N. perrinii '[does] not seem to spread into Libya towards the east' [44] (pg 514). In fact, it is likely to reach its maximum diffusion in the rocky plains of western Sahara, where it is spread and abundant [46] and sometimes it forms monospecific populations, while in central Sahara it is described as present only 'here and there' in mountains and rocky plateaux (e.g. Tassili n'Ajjer) [47, 48]. It grows north until South Morocco [26, 27], disappearing when passing the northern limit of the Seguiet el Hamra (around the $27^{\circ} 00^{\prime}$ $\mathrm{N}$ parallel) [47]. Indeed, a study about camel feeding behaviour in Central-South Morocco (near Ouarzazate) did not report $N$. perrinii among local forages, where it is instead substituted in its role by species of the same family, e.g. Salsola and Traganus species [49]. The plant is present in a scattered way in the Bir Lehlou area, while it is completely absent from the Hamada of Tindouf. 


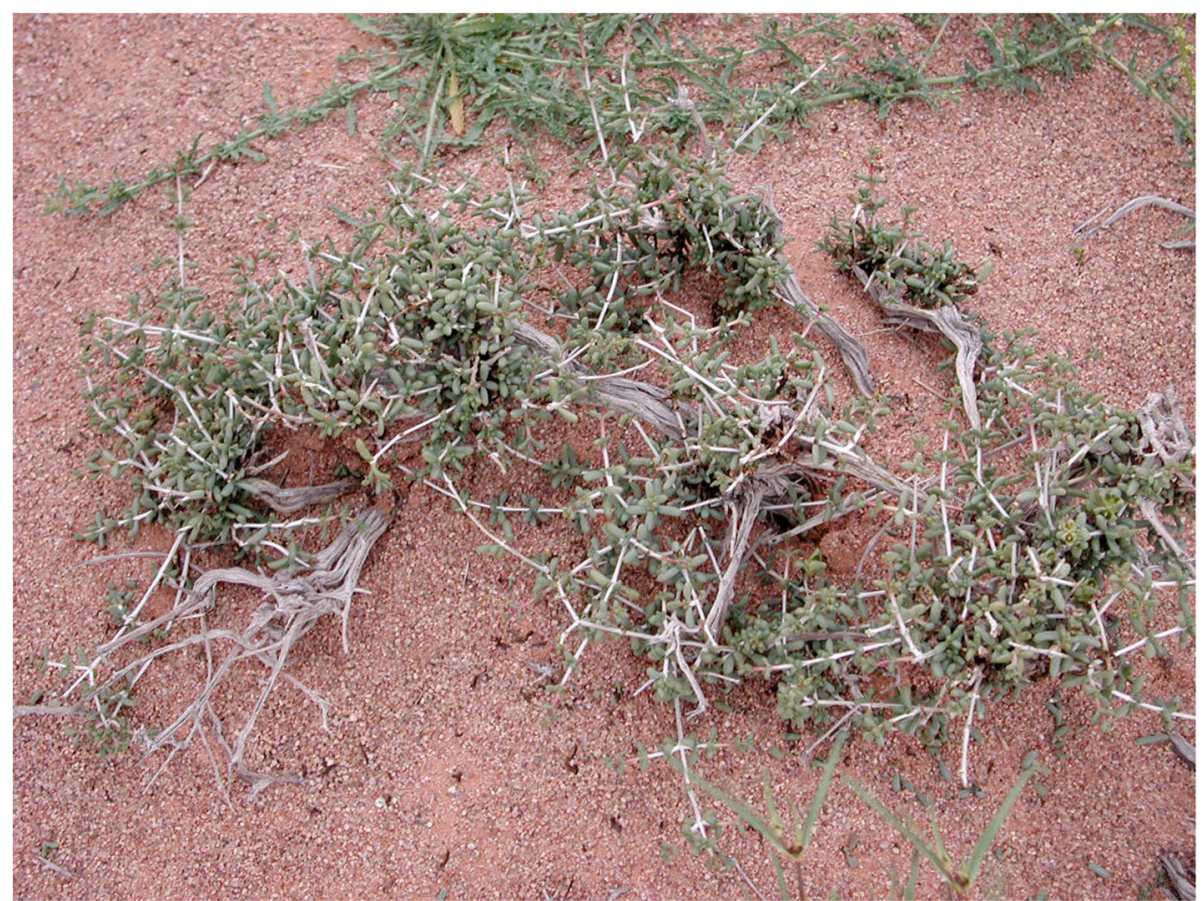

Fig. 4 Plant of N. perrinii (GV)

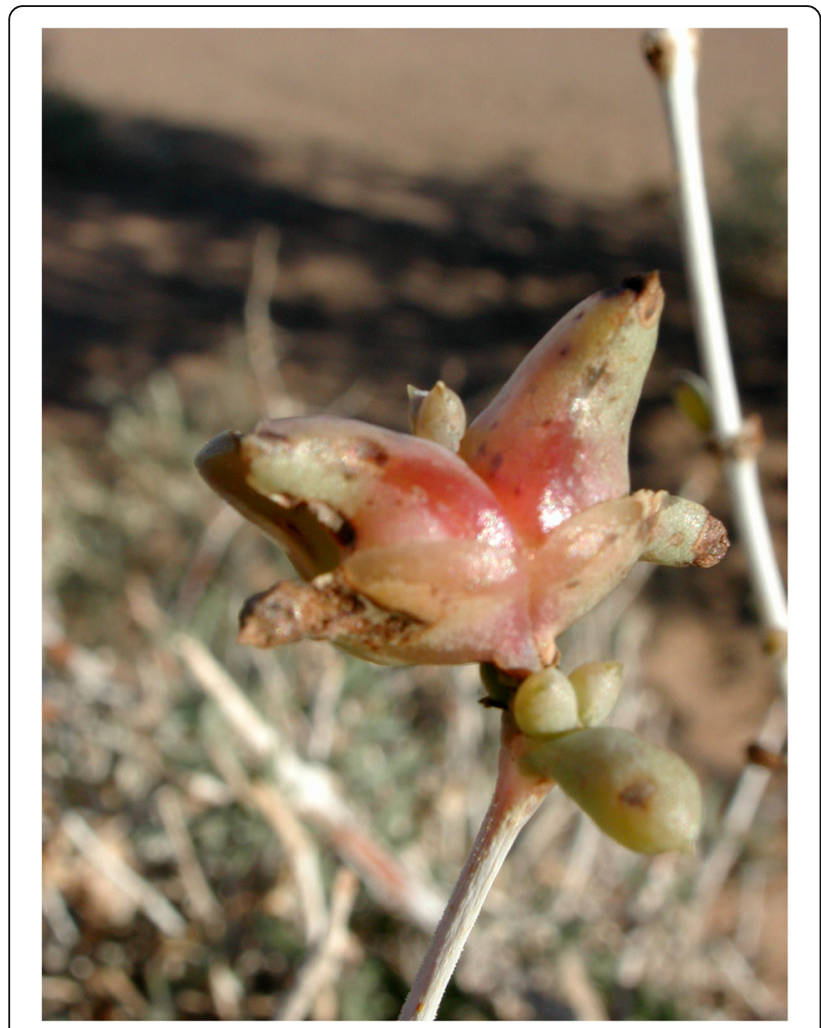

Fig. 5 Fruit of N. perrinii (GV)
Adamou reports, in his paper about camel husbandry in Algeria [50], that N. perrinii has disappeared from the region of Tindouf due to the degradation of the nomadic circuits; however, we rather argue that if the plant has ever been present in the Tindouf region, this was only in its southern part, across the border with Mauritania and Mali. According to our observations in Western Sahara, its northern limit in this area is north of Bir Lehlou, at about the $26^{\circ} 20^{\prime} \mathrm{N}$ parallel. According to the Sahrawi herders, the above defined northern limit corresponds to a dry riverbed called afrijed not far from Bir Lehlou. Moving southward, populations of $N$. perrinii become abundant in the Zemmur areas of Bir Nzarán, Tifariti, Mehris, Guelta Zemmur, and Bir Moughrein (in the Mauritanian territory east of the Guelta Zemmour), especially in rocky plains, at the base of mountain ranges, and along the borders of dry riverbeds $[25,51]$. In most of these areas, $N$. perrinii can be found commonly associated with Panicum turgidum in Acacia-Panicum steppes. Dobignard and colleagues [39] report $N$. perrinii in the hamada between Boukraa and Smara, in an 'arid sandy steppe', and state that it grows south until the Mauritanian Adrar, becoming the dominant salt species in the southern part of the territory (Tiris) [11], where it grows in rocky steppes along with Panicum turgidum or Stipagrostis species. Regs (rocky deserts) with a predominance of $N$. perrinii are present east of Bir Ganduz (in the extreme south of Western Sahara territory) [46]. Across all its range, N. perrinii does not grow in predominantly sandy areas and where 


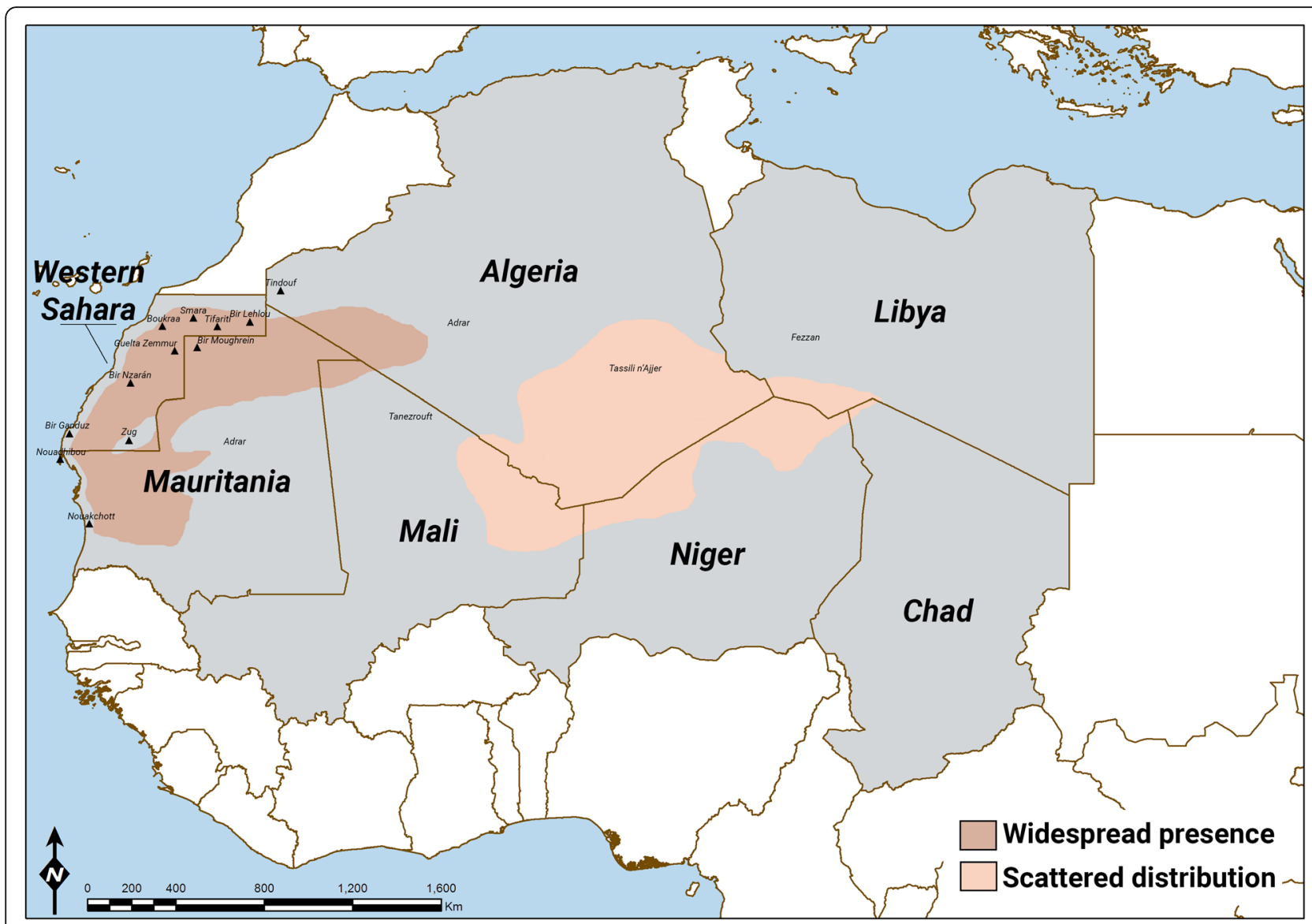

Fig. 6 Map of the distribution of N. perrinii

dunes appear (substituted by Cornulaca monocantha Delile); for example, it is reported as absent from the area south and east of Zug [46], where the Azéfal dune belt crosses the territory in direction north-east southwest. The western limit of its range are the oceanic coastal areas of Western Sahara and Mauritania, though it generally appears at some distance just of the coastal dune belts (the aguerguer, running in direction north-south just inland from the coast), and becomes progressively more abundant only towards the interior $[25,46,52]$. Outside Western Sahara, towards south and east, $N$. perrinii is present in discrete populations in non-dune areas of Central and North Mauritania, including the northern coastal area, where it is considered one of the best camel pastures [32, 53]. Monod [54] reports it between Aous and Jraif, in the French (Mauritanian) Adrar, just southeast from the border with Western Sahara, and it further seems to be an important species inland from Nouadhibou, while progressively becoming scarce moving further south. Naegelé [55] reports that Arthrocnemum fruticosum (L.) Moq. (Chenopodiaceae) is called 'askaf of the South' by Mauritanian nomads. Around Nouakchott, populations of askaf are reduced only to local sebhas, and the plant probably has its southern limit in the area around the $17^{\circ} \mathrm{N}$ parallel. The plant is also present throughout central and north Mali in sandy and rocky places, and again in areas of central Sahara as far east as the Libyan Fezzan and North Niger, as reported by Schulz [56] in his study of the flora and vegetation of that area. According to this author, $N$. perrinii is there the main representative (along with Salsola baryosma (Schult.) Dandy) of the Chenopodiaceae association, becoming rare towards north. $N$. perrinii's presence in the area is reported between the $23^{\circ} 56^{\prime}$ and $23^{\circ} 15^{\prime} \mathrm{N}$ parallels, and between the $11^{\circ} 48^{\prime}$ and $10^{\circ} 46^{\prime} \mathrm{E}$ meridians [56]. The species is notably absent from the tenefrut ('the desert of the desert' separating Moorish/Sahrawi and Tuareg nomadic circuits, across the Algerian Adrar and part of Mali), from East Algeria (it is not reported among the pastures of Ghardaia and Ouargla, where it is functionally substituted by $C$. monacantha and Traganum nudatum Moq. [57]), as well as from central Niger (e.g. it is not reported among the camel pastures of Agadez) [58,59]. In the areas of central Sahara, $N$. perrinii seems to be present with scattered populations, often limited to mountainous ranges [47]. This distribution hints at the possibility that the species 
was more widely distributed before the desertification of the Sahara began about 5,000 years ago, and that with increasing aridity its range restricted to (relatively wetter) mountainous ranges in central Sahara and toward the Atlantic coast in western Sahara.

\section{Ethnobotany and ethnoveterinary}

$N$. perrinii is used by the Sahrawi for medicinal and ethnoveterinary purposes. For centuries the nomads have used plant and animal resources from the desert for medicinal purposes, and N. perrinii makes no exception. The Sahrawi smash the fresh leaves of askaf and mix them with water to form a poultice applied topically to treat skin infections and wounds [17]. The dried and powdered stems are added to tea as digestive and for stomach ache and abdominal pain, while the dried fruit is added to tea in a similar way to treat diabetes and hypertension. Askaf is also important as a firewood source, especially to prepare tea and as a fire-initiator [22]. In its ecological role in the western Sahara ecosystem, it is sought after by wild ungulates such as gazelles, which used to constitute an important food source to Sahrawi nomads. N. perrinii is also used as an ethnoveterinary remedy to treat sick camels. The Sahrawi regard askaf grazing to be a treatment for several camel diseases such as knee inflammations, buguashish and zoran (i.e. salt deficiencies), and mindi (i.e. intestinal parasites). Aerial parts are burnt in front of the animal to treat skin ulcers from camelpox and respiratory infections [28].

However, it is in its crucial role as camel pasture that $N$. perrinii displays all of its importance for the Sahrawi pastoral SES (Fig. 7). It is regarded as the best and strongest pasture for camels', providing salts, strength and weight/fat to the animal. In their study of camel forages in Western Sahara, Volpato and Puri [21] found that askaf was the second most salient plant listed by Sahrawi herders [after Acacia tortilis and out of a total of 83 plants cited] and that it was mentioned by $75 \%$ of informants. Although $A$. tortilis, as well as $P$. turgidum and Astragalus vogelii Bornm. are also important plants for Sahrawi camel pastoralism, N. perrinii stands out as key forage due to its endemic distribution, to the crucial role as source of saline nutrients for western Saharan camels, and to being drought-resistant. Informants report that askaf is 'available when no other forage does' and associate its presence with camels' health in terms such as 'camels don't fall sick if there is askaf to graze, and they recover from an illness if they graze askaf', or again 'with askaf, a camel can transport $400 \mathrm{~kg}$ from Tindouf to the Moroccan coast and back' [21].

Camels graze often and preferentially on salty species, especially on plants with fleshy leaves that are high in protein and low in fiber content, and which develop green aerial parts during wet and dry periods alike [60,61]. Due to camels' need of six to eight times as much salt as other herbivores, halophytic plants represent the primary constituent of their diet, contributing up to one third of the total diet, with an even larger share during dry seasons and spells $[32,60]$. Western Saharan camels get much of their salts from $N$. perrinii, which plays a fundamental role in camel diets, especially in the cold season, i.e. before annuals have sprouted [10, 62, 63]. During this period, nomads may lead their herds to a 'salt cure' based on $N$. perrinii, a 45-days diet that 'cleans camels' blood' due to

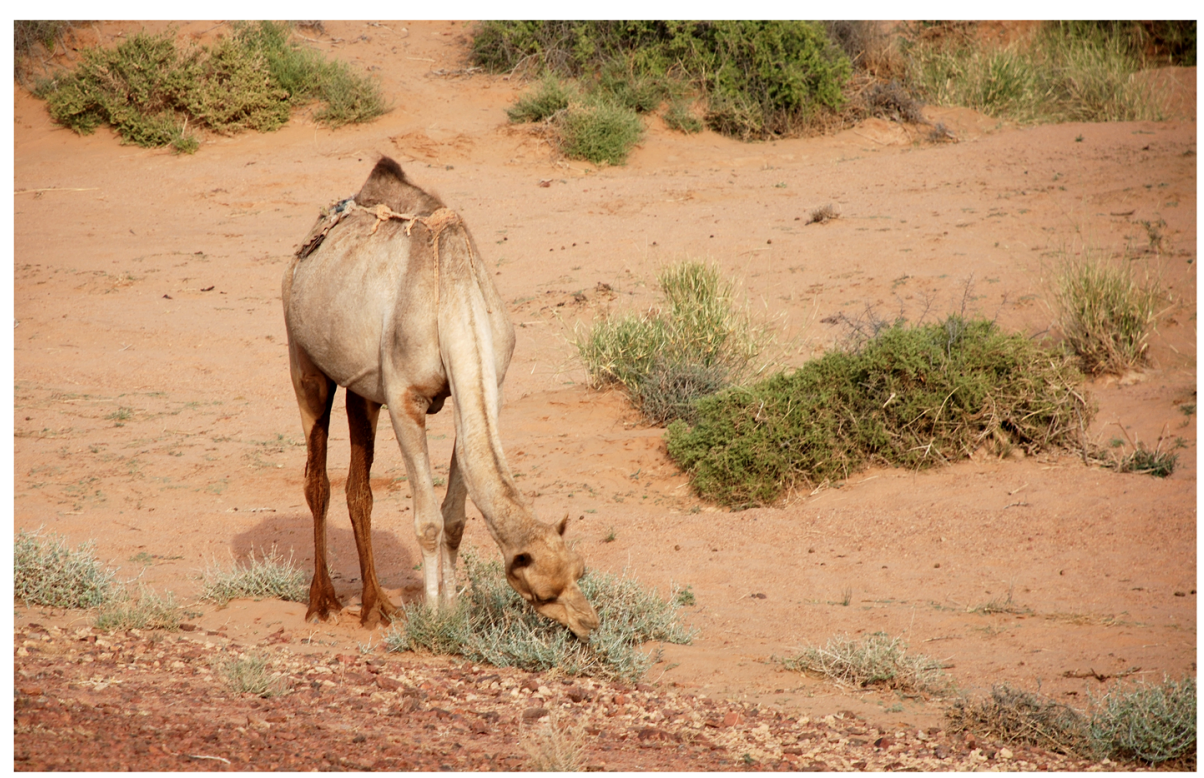

Fig. 7 Camel grazing askaf (GV) 
its purgative effect [23]. A similar importance is attributed to askaf by Moorish nomads of northern Mauritania, as reported by Correra [32] in his study of the dynamics of forage utilization in the Bank D'Arguin National Park. Local nomads report that askaf is one of the best pastures for camels, especially between January and October, corresponding to the local long dry season. Nomads and their camel herds from central Mauritania and Atar move north to Tiris and northern Mauritania once a year for saltcures based on N. perrinii. According to one Sahrawi informant, 'camels down there smell askaf from very far, and at the right period every year they want to move towards it.' 'Salt cures' by means of rotational visits to specific saltwater wells, to salty soils, or to areas with association of halophyte plants is an husbandry practice pursued by several African nomadic pastoralists (e.g., Moors, Tuareg, and Somali) [61, 64, 65].

Thus, $N$. perrinii is not only one of the most important plants of the everyday grazing of camels in western Sahara, but it also defines specific periods during the nomadic year in which it predominates in camels' diet and patterns of mobility are based on its distribution and availability. As reported by Boyer [23], Gauthier-Pilters [66], and Volpato and Puri [21], four nomadic seasons and respective patterns of camel dietary preferences can be distinguished in western Sahara; askaf is a main forage plants throughout the year, but it is during summers (from the beginning of June to the beginning of September), before the rains, when camels rely heavily on N. perrinii, that the plant stands out as a main element that beats the passing of time in Sahrawi nomadic lives.

\section{Ethnotaxonomy}

Given the importance of $N$. perrinii for camel health and survival among the Sahrawi, it is not surprising that the plant is a main element of their plant ethnotaxonomy and classification. This is true both for camel forages' classification as well as for general plant classification: askaf is the prototypical plant both for the category of summa plants (i.e. halophyte shrubs in generic classification) and of hatba or m'hatba plants (i.e. halophyte shrubs in camel forage classification) [21, 32]. Hatba includes thirteen species of salty forage plants (e.g. Salsola species, Traganum nudatum, Cornulaca monacantha) mostly belonging to the Chenopodiaceae family [21]. Distinct plants of hatba are preferentially distributed across different areas: $N$. perrinii grows in the rocky steppes of the interior, $C$. monacantha grows in sandy soils and dune areas, and Atriplex halimus L. grows along the coast [39].

The Sahrawi distinguish a 'true askaf' (simply called askaf) from a 'false askaf' (askaf el haibe). 'True askaf' is said to grow only in Western Sahara and northcentral Mauritania, whereas 'false askaf' is allegedly weaker (in terms of power as forage, e.g. nutritional properties) and smaller, and grows in south Algeria, northern Mali, and other parts of central Sahara (i.e. out of the Sahrawi's customary nomadic territory). The Sahrawi explain these differences on the basis that, in those surrounding areas, askaf has been historically disseminated through camel dung, and 'not because it belongs there.' False askaf's weakness and smaller size are then attributed to the different way of propagation of the species: dung versus seed. According to one informant, 'In Algeria there may be some askaf, but it is not as good as the one here [in Western Sahara], the plant in Algeria is weak, small, and is brought there by livestock. Askaf grows perfect only in Sahrawi territory.' Partly, this distinction supports and is supported by phytogeographical information presented above, and it is shown in Fig. 6 in terms of distinct color tones: $N$. perrinii is distributed in a main areal of western Sahara and a secondary areal of central Sahara; in the former, the species displays higher biomass production (i.e. it grows more) and higher abundance (i.e. individual plants per area) and hence it is key to local camel husbandry, while in the latter askaf is smaller and scattered and functionally substituted in its role by other halophyte species. Not by chance, the primary area of distribution of $N$. perrinii corresponds quite neatly with the customary grazing territory of the Sahrawi tribes, and the tribes before, since about 1,500 years. Thousandyear-old camel nomads of western Sahara, much like Sahrawi refugees today, struggled to get access to this important forage plant with their camel herds.

\section{Askaf and camel diseases}

The Sahrawi recognize strict and complex relationships between their camel herds and the desert ecosystem in terms of health [67]. They aim at rationally coupling the needs of their camels with the ever changing variability of grazing resources in time and space. Much of this rationale is related to and uses $N$. perrinii as term of reference and symbolic representation of the good characteristics of Western Sahara for camel husbandry versus the poor characteristics of surrounding areas. Askaf is central to the concept of health and disease as its distribution define territories where certain diseases are present or absent. In this way, askaf and camel diseases become also representative of a customary nomadic territory. Boundaries are defined conceptually and physically (i.e. by the presence of $N$. perrinii), and on these boundary-forming elements Sahrawi cultural identity is built and understood by nomads and refugees alike.

Among the diseases conceptually related to $N$. perrinii, the most important is buguashish, a salt and mineral deficit manifesting in lameness, progressive weakening, and bone fragility that results in spontaneous fractures, 
and caused by pasturing or traveling in sandy areas of Central Mauritania, Southwest Algeria, and Mali [28, 68]. Informants conceptualize buguashish in terms of presence or absence of $N$. perrinii. Given the importance and geographical distribution of $N$. perrinii in Western Sahara, Sahrawi herders tend to associate its presence with healthy camels and its absence (e.g. to the north, east, and south) with mineral deficits and disease. Therapy relies in moving camels to areas where they can graze askaf (or to the rocky soils where the species grows). Informants state that 'buguashish is a problem of the camels of the East, which do not eat askaf; is a problem of camels from sandy soils and dunes, where askaf does not grow; it occurs to camels that spend one or more years without eating askaf.' Mineral deficits (e.g. $\mathrm{NaCl}$ deficiency, phosphate/calcium disequilibrium) and associated health conditions (e.g. kraff disease, pica-pica) are relevant in many desert areas where camels live [65, 69-72]. These deficits especially occur when camels graze for long periods in phosphorus-poor soils. Camel health is instead supported by grazing in halophyte-rich areas, i.e. where $N$. perrinii is abundant. Thus, the conceptualization of buguashish in Sahrawi culture, in absence of knowledge of the phosphorus and its role, is built around a counterposition of positives ( $N$. perrinii and other salty plants, healthy status, rocky soils) and negatives (no $N$. perrinii, fractures and lameness in camels, sandy soils, e.g. the dune areas at the eastern periphery of their customary nomadic territories) [28].

Other conditions associated with the presence/absence of $N$. perrinii include homzi and ghesh (parasites of the respiratory system) to the north, and trypanosomiasis to the south and north [28]. Although it is one of the diseases most dreaded by African camel pastoralists $[73,74]$, trypanosomiasis is notably rather absent from the Sahrawi customary territories. It is instead generally present during rainy seasons in most of the remaining camel husbandry areas including Morocco (Tafilalet and Ouarzazate provinces), Central and Southern Mauritania, Mali, Chad, and Niger [75-77]. It appears that seroprevalence progressively decreases with decreasing annual precipitations towards the inner Sahara desert, whilst it is probably negligible in drier areas of Western and Central Sahara [28]. Sahrawi customary grazing areas are historically reported as free from trypanosomiasis [23, 68]. According to informants, death of trypanosomiasis-affected camels can be delayed or health restored if they are moved to graze from $N$. perrinii, which is here used as exemplificative of the trypanosomiasis-free Western Sahara ecosystem (i.e. if camels graze from $N$. perrinii it means that they are in Western Sahara and thus not exposed to trypanosomiasis vectors). Cures of salty plants are reported as treatments of trypanosomiasis by Monteil [68] and Curasson [78]. Like for buguashish, the Sahrawi's understanding of trypanosomiasis is embodied in the contrast between their customary areas (where the disease is absent and $N$. perrinii is abundant) and areas further to either the South or the Northwest Sahara (where the disease is present and $N$. perrinii is absent). Sahrawi mental map in relation to camel pastures is strictly related with the mental map associated to camel illnesses: 'Camels of Western Sahara are stronger and healthier; those coming from the East [e.g. Mali, Niger] are full of mahuar [scars from cauterizations for veterinary purposes]'. In essence, 'Askaf is a pasture that treats camel diseases; a camel can live thirty years here without getting sick as long as there is askaf and some rain.'

\section{Askaf and the taste of camel milk}

The importance of $N$. perrinii for the Sahrawi is reflected in the organoleptic characteristics it gives to camel milk, Sahrawi's staple food. The Sahrawi recognize in detail the relations between forages and the taste, smell, or health and nutritional properties of camel milk. Sahrawi practices around the taste and smell of camel products are embedded in Sahrawi cultural values and identity [21].

The taste and smell of the plants grazed in each area and season is reflected in the taste and smell of milk. Taste and smell are representative of, and attached to, customary grazing areas, and hence also an element of cultural identity. N. perrinii is exemplary in this process of cultural identity construction, and Sahrawi nomads perceive that the 'perfect' light-salty taste of $N$. perrinii in camel milk is characteristic of Western Sahara, in contrast with other nomads (e.g. Tuareg), their territory (where the plant is absent), and the taste of that milk. Consuming milk from an animal that grazed from $N$. perrinii is regarded as pleasant due to its good taste, and healthy due to the medicinal and nutraceutical properties of the plants 'embedded' into the properties of the milk.

In these tastes and smells, the Sahrawi nomads and refugees recognise those of their (lost and partly recovered) homeland, and further associate them with concepts such as freedom (e.g. of crossing the desert with camels), belonging (e.g. to a group of people with specific food practices), and dignity (i.e. an individual or groups sense of self-respect and self-worth). Culturallyrelevant foods and their taste are sought beyond their nutritional and health properties, and food habits, preferences, and taste are constituents of values and cultural identities. Refugees pursue productive and market activities and use subsistence resources to reduce dependence on food aid and obtain 'their' foods. In this way the taste of these foods is related to the struggle of the Sahrawi refugees to recover their culture and livelihoods. Furthermore, the Sahrawi distinguish 
four nomadic seasons and respective patterns of camel dietary preferences. In each season, different main grazing plants give different taste to the milk. The taste of the milk becomes representative of the rhythms of seasons and years dictated by camels and local desert ecologies, and not by camps' limbo and international policies, or by queues to get food aid. Thus, milk taste represents time, space, and associated values and feelings. Refugees contrast fresh camel milk and its taste with powder milk. The first represents 'life as it should be', it is socially accepted and culturally meaningful (Fig. 8). The second, received as food aid in the camps, represents powerlessness, alienation, and loss. Fresh camel milk makes life in the camps less distressing, re-activating hope and sense of belonging. One informant emphatically explained: 'The best life is when you are with camels in an area with askaf and you drink the milk from those camels'. Drinking milk with the distinctive taste given by askaf and/or other pastures of the nomadic territories is also a main desire of elderly in the camps. Bringing one's elderly to the customary nomadic areas to drink fresh camel milk is then a mayor social expectation that refugees try to meet by acquiring camels and through temporary nomadism. This provides older refugees with a much-desired glimpse of their pre-war nomadic life and its products (Fig. 9).

\section{Askaf and cultural and political identity}

Sahrawi cultural identity is related to the central elements of their nomadic livelihoods and to the territory where these take place. $N$. perrinii is a main element of this identity. Among the elements that symbolically define their own pastoral SES, the Sahrawi include askaf, as well as camel-based subsistence products and camelassociated skills and knowledge [16], and specific camel breeds [79]. Askaf becomes a claim to a national territory delimited by its presence, where extensive camel husbandry and associated knowledge, culture, and values are pursued since hundreds of years.

Nomadic tribes substantially engage with each other in order to have access to grazing areas (i.e. with better grazing resources, absence of diseases and vectors, etc.). Resources and characteristic features of these areas are foundational to tribes' cultural identity (and capacity of collective mobilization to defend those grazing areas). This is the case with $N$. perrinii and its centrality in 'camel narratives' among the Sahrawi. The occupation of areas fit for camel husbandry is conceptualised around the absence of certain diseases (e.g. trypanosomiasis, buguashish), and understood in terms of contraposition between areas where these diseases occur and their characteristics (e.g. sandy areas, wetter areas, areas without askaf) and customary grazing areas (Western Sahara and northern Mauritania, presence of askaf). The set of relations established in the badyia are contrasted with the predominant relations in the outer (strangers') territories, and embedded into Sahrawi cultural roots. So, the 'ideal picture' of Sahrawi camel husbandry is characterized by absences as well as presences: $N$. perrinii and its taste in camel milk are defining presences; trypanosomiasis, buguashish and other diseases are defining absences.

The Sahrawi construe a further contraposition in terms of differences between the refugee camps and the customary grazing territories of Western Sahara, in

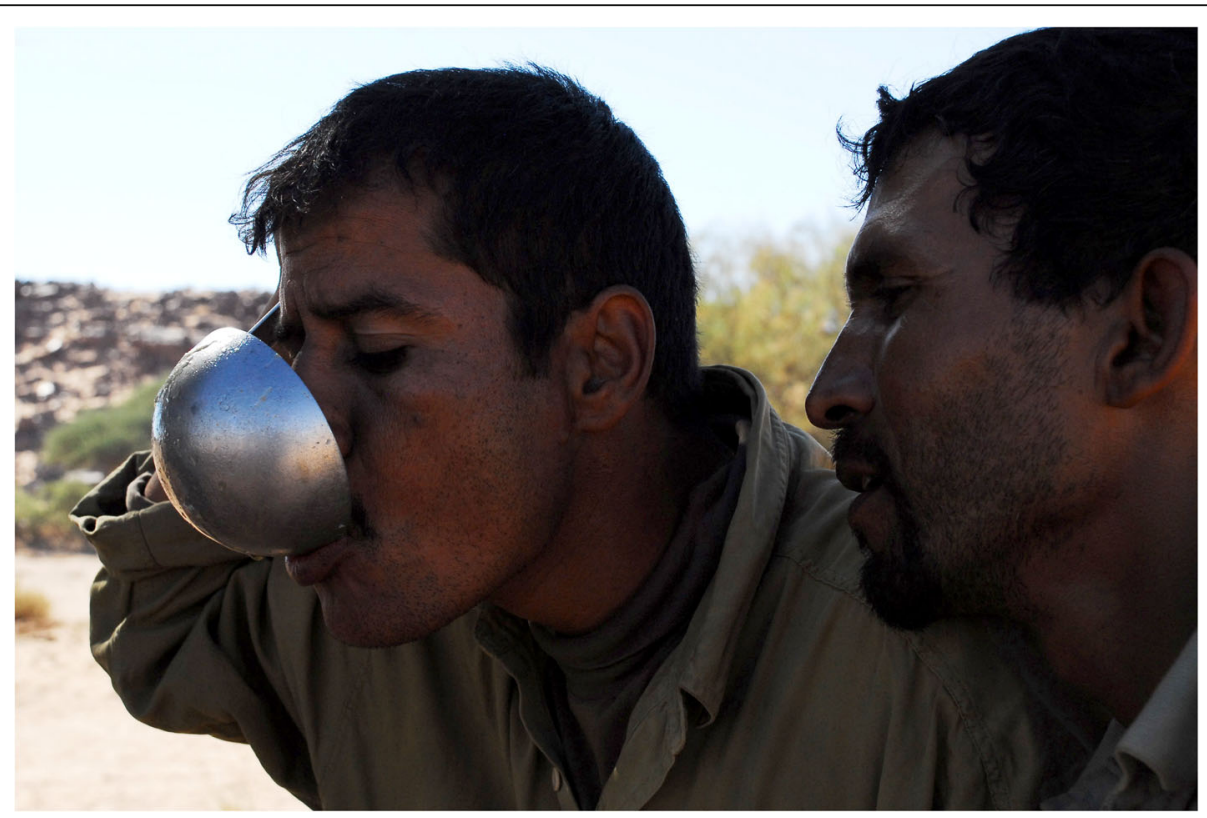

Fig. 8 Refugees drinking camel milk (GV) 


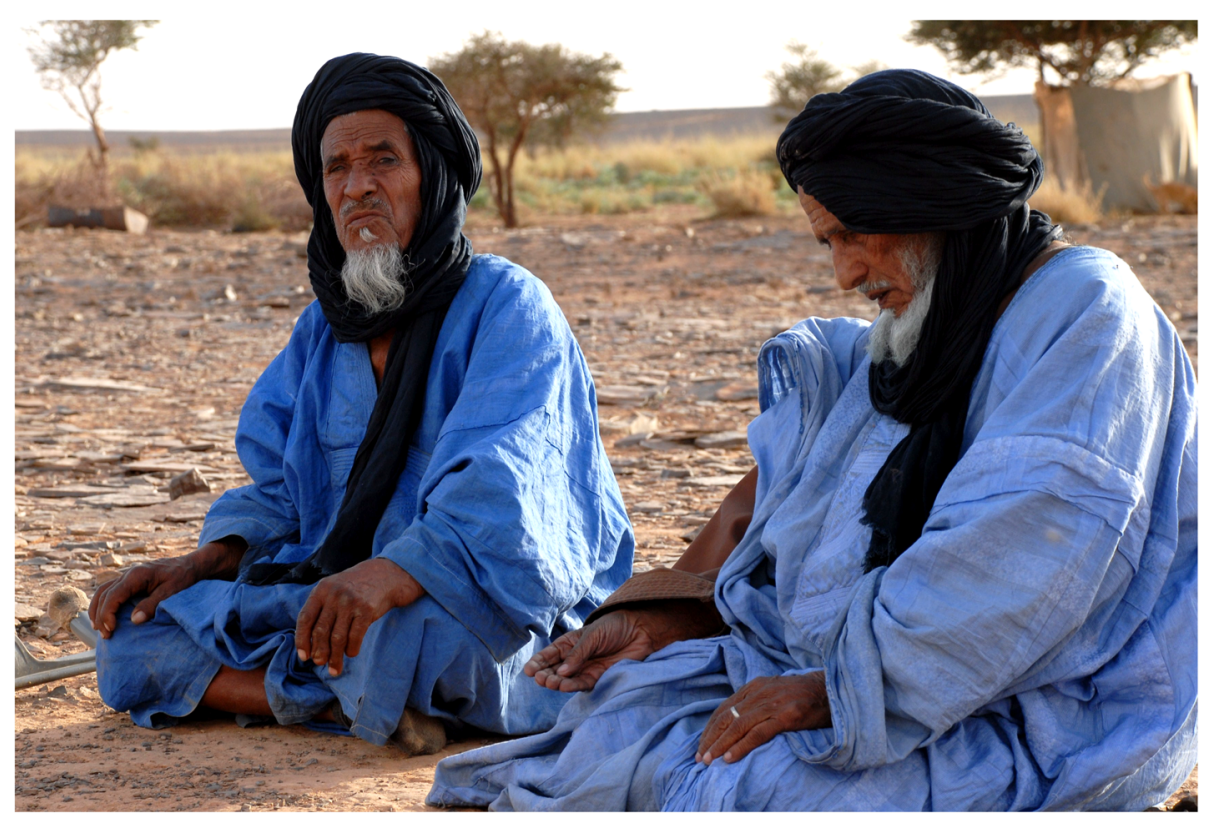

Fig. 9 Old refugees in the former nomadic territories (GV)

terms of presence/absence of askaf, constraints in camel husbandry, and taste of camel milk. These contrapositions are embedded into a narrative that symbolically represents refugee camps as places where traditional livelihoods can't be pursued, where camels do not live and produce at their best, where camel products do not have the 'right taste', and where the food obtained through aids (e.g. powder milk) do not adhere to Sahrawi gastronomic standards.

In surrounding nomadic areas, there are regions characterised by the presence of specific threatening camel illnesses, unfavourable environmental conditions, and/or unfavourable political situations. Among these territories, we note South Morocco, in the regions North of Seguia el Hamra and of Tarfaya. There, it historically existed a geographical border between different SESs, with SESs based on sedentary small livestock breeding and small-scale farming to the north, and nomadic camel pastoralism to the south, through a continuum of diversified smallerscale SESs. In these areas of Southern Morocco, the Sahrawi state that the risk for camels of getting illnesses such as buguashish or homzi increases, important camel pastures are absent, and general environmental conditions are less favourable for camel breeding (i.e. higher humidity and oceanic climate). Given the context in which Sahrawi nomads became refugees and the conditions of life in the refugee camps, these constructions around $N$. perrinii become a statement of political identity: through the narratives around askaf, the Sahrawi politically claim their customary territory as homeland.

\section{Conclusions}

Pastoral social-ecological systems worldwide are rooted in the livestock species and in the grazing resources available in a territory and utilized through the deployment of different forms of mobility within a system of social relations and culture. This study has provided an account of a key species and its relations using as case study the role and importance of the grazing plant Nucularia perrinii for the camel-based pastoral systems of the Sahrawi nomads and refugees of Western Sahara.

We reported first on the botany of $N$. perrinii in terms of Saharan distribution and on its taxonomy among Saharan pastoralists, and then on its material (i.e. as camel forage and veterinary remedy) and cultural (i.e. to define customary grazing territories, as main element of cultural identity) importance among the Sahrawi. This halophyte species, called askaf, is understood by the Sahrawi as representative and emblematic of the goodness of Western Sahara environment for camel husbandry. Its populations define the boundaries of customary grazing territories, and as such narratives about askaf are embedded into conceptualisation of camel diseases and their distribution, into Sahrawi gastronomic and cultural standards (i.e. in the taste given by askaf to camel milk), and further into Sahrawi identity. The counterposition that the Sahrawi construe between askaf presence, on the one hand, and with its absence and the presence of camel diseases on the other hand signals that askaf is embedded into Sahrawi cultural identity. The counterposition of askaf-tasting camel milk with powder milk made available 
in the refugee camps by food aid signals the antithesis between the positive values of nomadic life and the negative values of life as refugees in the camps. As a whole, these results suggest that $N$. perrinii is used by the Sahrawi as important grazing resource but also as a tool in which political narratives of territorial claims and selfdetermination (versus Morocco for the Western Sahara, and versus the refugee camps for nomadic livelihoods based on freedom of movement) are woven.

We conclude that $N$. perrinii ties the ecology of the Western Sahara desert with camel husbandry and associated livelihoods, and further with the culture and worldview of the Sahrawi nomads and refugees. We contribute to the understanding of the key roles of grazing species in extensive pastoral SESs, and of these species' importance for subsistence livelihoods. These findings enhance our understanding of the critical role that specific pastures have in pastoral SESs, which not only provide sustenance to pastoralists' herds but are also cultural elements woven into the fabric of pastoralists' values, beliefs, and identity.

\section{Endnote}

${ }^{1}$ Throughout this paper, we use the definition 'western Sahara' when referring to the western part of the Sahara desert, while we spell 'Western Sahara' when referring to the country (former Spanish Sahara) and its territory. Western Sahara is thus a politically-delimited part of western Sahara.

\section{Acknowledgements}

We are very thankful to many Sahrawi refugees and nomads for their patience, kindness, and hospitality during the interviews. We also thank the Italian NGO Africa'70 and the Sahrawi Veterinary Services of the SADR (Sahrawi Arab Democratic Republic) for logistical support and cooperation.

\section{Funding}

Funds were granted to Gabriele Volpato by Ceres Research School of the Wageningen University, The Netherlands, as part of his PhD research on recovery and adaptation of subsistence practices and ethnobiological knowledge among the Sahrawi refugees. Antonello Di Nardo was supported by the BBSRC DTA (1094618 and BBS/E///00001642) and by the BBSRC Institute Strategic Programme Grant on Livestock Viral Diseases granted to The Pirbright Institute.

\section{Availability of data and materials}

The dataset analysed for this study is available from the corresponding author on request. Voucher specimens were deposited in the National Herbarium of The Netherlands (Wageningen Branch - Herbarium Vadense). Herbarium specimens for N. perrinii are GV1047 and GV2042.

\section{Authors' contributions}

GV and partly ADN carried out fieldwork in Western Sahara. Both authors composed the literature review, drafted the manuscript, read and approved the final manuscript.

\section{Competing interests}

The authors declare that they have no competing interests.

\section{Consent for publication}

Consent to publication of any pictures included in the paper has been obtained verbally from the study participants.

\section{Ethics approval and consent to participate}

Prior informed consent was obtained verbally before interviews were conducted. Participants were given an explanation of the aims, methodology, and outcomes of the study. The ethical guidelines followed were those adopted by the American Anthropological Association [80] and the International Society of Ethnobiology [81].

\section{Author details}

${ }^{1}$ Center for Integrative Conservation Research, University of Georgia, Athens, GA, USA. ${ }^{2}$ The Pirbright Institute, Pirbright, Woking, Surrey, UK.

Received: 14 October 2016 Accepted: 20 January 2017

Published online: 08 February 2017

\section{References}

1. Berkes F, Folke C. Linking social and ecological systems: Management practices and social mechanisms for building resilience. Cambridge: Cambridge University Press; 2000.

2. Liu J, Dietz T, Carpenter SR, Folke C, Alberti M, Redman CL, Schneider SH, Ostrom E, Pell AN, Lubchenco J, Taylor WW, Ouyang Z, Deadman P, Kratz T, Provencher W. Coupled human and natural systems. Ambio. 2007;36:639-49.

3. Garibaldi A, Turner N. Cultural keystone species: Implications for ecological conservation and restoration. Ecol Soc. 2004;9:1.

4. Manning $A D$, Fischer J, Lindenmayer DB. Scattered trees are keystone structures - Implications for conservation. Biol Cons. 2006;132:311-21.

5. Bollig M, Schnegg M, Wotzka H. Pastoralism in Africa: past, present and future. Oxford: Berghahn; 2013.

6. Galvin K. Transitions: pastoralists living with change. Annu Rev Anthropol. 2009;38:185-98.

7. Homewood K. Ecology of african pastoralist societies. Oxford: James Currey Ltd; 2008.

8. Caratini S. Les Rgaybat (1610-1934). 1: Des chameliers à la conquete d'un territoire. Paris: L'Harmattan; 1989.

9. Caratini S. Les Rgaybat (1610-1934). 2: Territoire et société. Paris: L'Harmattan; 1989.

10. Caro Baroja J. Estudios saharianos. Madrid: Consejo Superior de Investigaciones Cientificas; 1955.

11. Mercer J. Spanish Sahara. London: George Allen \& Unwin Ltd; 1976.

12. San Martin P. Western Sahara: the refugee nation. Cardiff: University of Wales Press; 2010

13. Herz M. From camp to city: Refugee camps of the Western Sahara. Zürich: ETH Studio Basel, Lars Müller Publishers; 2013.

14. Mundy JA. Performing the nation, pre-figuring the state: the Western Saharan refugees, thirty years later. J Mod Afr Stud. 2007;45:275-97.

15. Dedenis J. La mobilité régionale de la société sahraouie des camps de réfugiés: une ressource pour un mieux-vivre? Poitiers, France: Université de Poitiers, Migrations Internationales, espaces et sociétés (MIGRINTER); 2005.

16. Volpato $G$, Howard $P$. The material and cultural recovery of camels and camel husbandry among Sahrawi refugees of Western Sahara. Pastoralism. 2014;4:7.

17. Volpato G, Kourková P, Zelený V. Healing war wounds and perfuming exile: the use of vegetal, animal, and mineral products for perfumes, cosmetics, and skin healing among Sahrawi refugees of Western Sahara. J Ethnobiol Ethnomed. 2012;8:1-19.

18. Volpato G, Rossi D, Dentoni D. A Reward for patience and suffering Ethnomycology and commodification of desert truffles among Sahrawi refugees and nomads of Western Sahara. Econ Bot. 2013;67:147-60.

19. Caratini S. La prison du temps. Les mutations sociales à l'oeuvre dans les camps de réfugiés sahraouis. Deuxième partie: l'impasse. Afr Contemp. 2007;2:181-97.

20. Brooks N, Chiapello I, Di Lernia S, Drake N, Legrand M, Moulin C, Prospero J. The climate-environment-society nexus in the Sahara from prehistoric times to the present day. J Nor Afr Stud. 2005;10:253-92.

21. Volpato G, Puri R. Dormancy and revitalization: the fate of ethnobotanical knowledge of camel forage among Sahrawi nomads and refugees of Western Sahara. Ethnobot Res Appl. 2014;12:183-210.

22. Barrera I, Ron ME, Pajaron S, Sidi Mustapha R. Sahara Occidental. Plantas y Usos. Usos y costumbres del pueblo saharaui relacionados con los recursos vegetales. Estudio etnobotánico del Sahara Occidental. Madrid: Universidad Complutense de Madrid y Ministerio de Cultura de la República Árabe Saharaui Democrática; 2007. 
23. Boyer JR. Contribution à l'étude de l'élevage camelin au Sahara Occidental. Le Regueibat et son chameau. Ecole Nationale Veterinaire D'Alfort, Faculté de Médecine de Paris; 1962.

24. Gauthier-Pilters H. Observations sur l'écologie du dromadaire dans l'ouest du Sahara. Bull Inst Fondarn Afr Noire. 1965;27:1534-608.

25. Guinea A. Catálogo razonado de las plantas del Sahara español. An Jard Bot Madr. 1948;8:357-442.

26. Lebrun J. Catalogue des plantes vasculaires de la Mauritanie et du Sahara Occidental. Boissiera. 1998;55:1-322.

27. Ozenda P. Flore et Végétation du Sahara. 3rd ed. Paris: CNRS Éditions; 1991.

28. Volpato G, Lamin Saleh SM, Di Nardo A. Ethnoveterinary of Sahrawi pastoralists of Western Sahara: camel diseases and remedies. J Ethnobiol Ethnomed. 2015;11:1-22.

29. Maeno K, Piou C, Ely S, Mohamed S, Jaavar M, Babah M, Nakamura S. Field observations of the sheltering behavior of the solitarious phase of the desert locust, schistocerca gregaria, with particular reference to antipredator strategies. Jpn Agric Res Q. 2012;46:339-45.

30. Maeno KO, Piou C, Ely SO, Babah MAO, Pelissie B, Mohamed SO, Jaavar ME, Etheimine M, Nakamura S. Plant size-dependent escaping behavior of gregarious nymphs of the desert locust, schistocerca gregaria. J Insect Behav. 2013;26:623-33.

31. Quezel PS. Nouvelle flore de l'Algérie et des regions désertiques méridionales. Editions du Centre National de la Recherche Scientifique: 1963.

32. Correra A. Dynamique de l'utilisation des ressources fourrageres par les dromadaires des pasteurs nomades du Parc National du Banc d'Arguin (Mauritanie). Museum National d'Histoire Naturelle de Paris, Ecologie et gestion de la biodiversité; 2006.

33. Alexiades M. Selected guidelines for ethnobotanical research: a field manual. New York: New York Botanical Garden; 1996

34. Cunningham AB. Applied ethnobotany. People, wild plant use and conservation. London: Earthscan Publications Ltd; 2001

35. Nolan JM, Turner NJ. Ethnobotany: the study of people-plant relationships. In: Anderson EN, Pearsall D, Hunn E, Turner N, editors. Ethnobiology. Hoboken: Wiley-Blackwell; 2011. p. 133-47.

36. Bernard HR. Research methods in anthropology. Qualitative and quantitative approaches. 4th ed. Lanham: Altamira Press; 2006.

37. Weller SC. Structured interviewing and questionnaire construction. In: Bernard HR, editor. Handbook of Methods in Cultural Anthropology. Walnut Creek: Altamira Press; 1998. p. 365-409.

38. Dobignard A, Jacquemoud F, Jordan D. Matériaux pour la connaissance floristique du Sahara occidental et de l'Anti-Atlas méridional. II. Leguminosae à Compositae. Candollea. 1992;47:397-481.

39. Dobignard A, Jacquemoud F, Jordan D. Matériaux pour la connaissance floristique du Sahara occidental et de l'Anti-Atlas méridional. I : Pteridophyta à Rosaceae. Candollea. 1992:47:113-79.

40. Battandier JA. Notes sur quelques plantes rapportées du Touat par le Dr Perrin. Nouveau genre de Salsolacées. Bull Soc Bot France. 1903:50: 468-70

41. Battandier JA. Nucularia Batt. Nouveau genre de Salsolacées, description complétée et rectfiée. Bull Soc Bot France. 1904;51:433-34.

42. Baba ASOM. Los fitónimos más frecuentes en el dialecto hassāniyyä. Anaquel de Estudios Árabes. 2006;17:173-87.

43. Benchelah AC, Bouziane H, Maka M, Ouahes C. Fleurs du Sahara. Voyage ethnobotanique avec les Touaregs du Tassili. Paris: Ibis Press-Atlantica; 2000.

44. Quezel P. Analysis of the Flora of Mediterranean and Saharan Africa. Ann Mo Bot Gard. 1978;65:479-534.

45. Lebrun JP. Introduction á la flore d'Afrique. Paris: CIRAD, Ibis Press; 2001.

46. Guinea A. Aspecto forestal del desierto. La vegetación leñosa y los pastos del Sahara español. Madrid: Instituto Forestal de Investigaciones y Experiencias; 1945.

47. Maire R. Mission du Hoggar II. In: Etudes sur la flore et la vegetation du Sahara Central. Mem Soc Nat Afrique Nord. 1933;3:1-280.

48. Maire R. Mission du Hoggar III. In: Etudes sur la flore et la végétation du Sahara Central. Alger: Imprimeries 'La Typo-Litho'; 1940.

49. Aich EA, Narjisse H, Moumen I. Dromedary feeding behaviour in the southern steppe of Morocco. In: Tisserand $J$, editor. Elevage et alimentation du dromadaire. Zaragoza: CIHEAM; 1995. p. 43-9.

50. Adamou A. L'élevage camelin en Algérie: quel type pour quel avenir? Sécheresse. 2008;19:253-60.

51. Maire R. Contribution a l'étude de la Flore du Sahara occidental. Le Botaniste. 1949:34:293-308
52. Murat M. La végétation du Sahara occidental en zone espagnole. C R Séances Soc de Biogéogr. 1939;137:63-7.

53. Diagana D. Contribution à l'étude de l'élevage du dromadaire en Mauritanie. Faculty of Medicine and Pharmacy, University of Dakar, 1977.

54. Monod T. Contributions á l'étude du Sahara occidental. Paris: Librairie Larose; 1939.

55. Naegelé A. Contributions á l'étude de la flore et des groupements végétaux de la Mauritanie. Bull de I'IFAN. 1958;2:293-305.

56. Schulz E. Zur Flora und Vegetation der Randgebiete des Murzuk-Beckens (Fezzan-Libyen und Nord-Niger). Willdenowia. 1979;9:239-59.

57. Chehma A, Djebar MR, Hadjaiji F, Rouabeh L. Étude floristique spatio-temporelle des parcours sahariens du Sud-Est algérien. Sécheresse. 2005;16:275-85.

58. Chaibou M. Productivité Zootechnique du Desert: Le Cas du Bassin Laitier d'Agadez au Niger. Université de Montpellier II, Biologie des Systèmes intégrés, Agronomie, Environnement; 2005.

59. Chaibou M, Faye B. Fonctionnement des élevages camelins de la zone périurbaine d'Agadez au Niger: enquête typologique. Rev Elev Med Vet Pays Trop. 2005;58:273-83.

60. Gauthier-Pilters H, Dagg Al. The Camel: its evolution, ecology, behavior and relationship to man. Chicago: The University of Chicago Press; 1981.

61. Wilson RT. The nutritional requirements of camel. Options Méditérr. 1989;2: $171-79$

62. Doménech A. Algo sobre el Río de Oro. Madrid: Instituto Editorial Reus; 1946.

63. Guinea A. El Sahara Español. Madrid: Consejo superior de investigaciones cientificas, Instituto de Estudios Africanos; 1949.

64. Farah KO, Nyariki DM, Ngugi RK, Noor IM, Guliye AY. The Somali and the camel: Ecology, management and economics. Anthropologist. 2004;6:45-55.

65. Farid MFA. Water and minerals problems of the dromedary Camel (an overview). Options Méditérr. 1989;2:111-24.

66. Gauthier-Pilters H. Observations sur l'ecologie du dromedaire dans le Sahara Nord-Occidental. Mammalia. 1961:25:195-280.

67. Volpato G, Di Nardo A, Rossi D, Lamin Saleh SM, Broglia A. 'Everybody knows', but the rest of the world: the case of a caterpillar-borne reproductive loss syndrome in dromedary camels observed by Sahrawi pastoralists of Western Sahara. J Ethnobiol Ethnomed. 2013:9:5.

68. Monteil V. Essai sur le chameau au Sahrara Occidental. Saint-Louis du Senegal: Centre IFAN - Mauritanie; 1952.

69. Bengoumi M, Robins SP, De la Farge F, Coxam V, Davicco MJ, Barlet JP. Water restriction and bone metabolism in camels. Reprod Nutr Dev. 1996:36:545-54.

70. Blajan L, Lasnami K. Nutrition et pathologie du dromadaire. Options Méditérr. 1989;2:131-39.

71. Centre de Coopération Internationale en Recherche Agronomique pour le Développement. La maladie du kraft en Tunisie. CIRAD. 2007. http:// camelides.cirad.fr/fr/science/kraft tunisie.html. Accessed 18 Jan 2017.

72. Faye B. Guide de l'élevage du dromadaire. Libourne: Sanofi Santé Nutrition Animale; 1997.

73. Dirie MF, Wallbanks KR, Aden AA, Bornstein S, Ibrahim MD. Camel Trypanosomiasis and Its Vectors in Somalia. Vet Parasitol. 1989:32:285-91.

74. Hoare CA. Tsetse-borne trypanosomiases outside their natural boundaries. In: The Trypanosomes of Mammals: A Zoological Monograph. Oxford and Edinburgh: Blackwell Scientific Publications; 1972. p. 267-77.

75. Dia ML, Diop C, Aminetou M, Jacquiet $P$, Thiam A. Some factors affecting the prevalence of Trypanosoma evansi in camels in Mauritania. Vet Parasitol. 1997:72:111-20.

76. Pacholek X, Gamatic D, Franek SG, Tibayrene R. Prevalence of Trypanosoma evansi trypanosomosis in young camels in west Niger. Rev Elev Med Vet Pays Trop. 2001:44:177-82.

77. Rami M, Atarhouch T, Bendahman MN, Azlaf R, Kechna R, Dakkak A. Came trypanosomosis in Morocco 2. A pilot disease control trial. Vet Parasitol. 2003;115:223-31.

78. Curasson A. Hygiéne et maladies du dromedaire en Afrique occidentale francaise. Gorée: Imprimerie du Gouvernement général; 1926.

79. Volpato G, Dioli M, Di Nardo A. Piebald camels. Pastoralism. Accepted.

80. American Anthropological Association. Code of Ethics of the American Anthropological Association. American Anthropological Association. 2009. http:// s3.amazonaws.com/rdcms-aaa/files/production/public/FileDownloads/pdfs/ issues/policy-advocacy/upload/AAA-Ethics-Code-2009.pdf. Accessed 18 Jan 2017.

81. International Society of Ethnobiology. International Society of Ethnobiology Code of Ethics (with 2008 additions). International Society of Ethnobiology. 2006. http://www.ethnobiology.net/what-we-do/core-programs/ise-ethicsprogram/code-of-ethics/code-in-english/. Accessed 18 Jan 2017. 